\title{
BLACK RAILS IN REGINA - AN INCREDIBLE HYPOTHETICAL
}

FRANK BRAZIER, 2657 Cameron Street, Regina, Saskatchewan. S4T 2W5

May 18, 1992, was a Monday and all of Canada was taking a holiday to celebrate Queen Victoria's birthday. It was a pleasant day, so after lunch I drove alone to Condie, then visited Brown's Slough, $3.2 \mathrm{~km}$ from the Condie road. I turned south and, as I reached a flooded ditch on the west side of the road, I disturbed a very small black bird which flew ahead of my car a little way before it dropped out of sight. This manoeuvre was repeated several times for the entire length of the flooded ditch (which I later paced off and found to be about $69 \mathrm{~m}$ ). Each time the bird flew I could see that it was very small, black and the whirring wings produced a pale stripe their entire length. Although I had never seen one before, I was sure it was a Black Rail.

When the bird reached the end of the ditch, it again dropped out of sight but this time when I drove slowly forward it flew to the other side and then continued back on that side. I watched it through the rear window and noted that there was some debris where it dropped into cover finally, so I could find the spot.

I had to drive to the end of the road before I could turn and get back to the point where the bird had disappeared, an interlude of about four minutes. I shut off the engine and waited for 15 minutes, but at 2:45 p.m. there was still no sign of the bird. During my wait a Sora walked near the spot I was watching and it was evident that the Sora was much larger than the bird I had seen. I never saw it again, so I never got a good picture of it - only a tiny black bird, the size of a small sparrow, flying away from me.

I was hoping for an independent confirmation of my identification, but I was unable to reach Robert Kreba, a staff member at the Saskatchewan Museum of Natural History (SMNH) and a knowledgeable birder. Later that afternoon I reached Fred Lahrman by telephone and described my experience of the afternoon. He said he had a copy of Bent's Marsh Birds and would bring it to me the next morning when we met for coffee. This he did but nowhere in it could I find a description of a flying Black Rail. $^{1}$

On 21 May, Fred telephoned me to report that the Bird Alert had a notice in it that someone, unnamed, had seen a number of Black Rails near the Wascana Country Club. After I had listened to the message I got in touch with Robert Kreba and told him about it. He was unaware of it but later telephoned me to advise that the report had been made by Nels Arbinson. I called Nels, who told me that on 18 May he had been in a canoe, alone, and when he paddled under the bridge by the Country Club (locally known as Rainbow Bridge) he saw a very small, black bird with a black bill and a pattern of white feathers on the back and wings. It was foraging among the reeds. As he made no noise, Nels was able to 
get quite close without alarming the bird. He continued down Wascana Creek for about a mile until he reached another bridge (the one just east of Monica Farm) and at intervals he saw four more of the birds. One of them flew and he noticed the pale wing stripe.

At home he consulted his field guide and concluded the birds could only be Black Rails, a species which he had never seen before. He put the message on the Bird Alert. He told me he was going back with a camera. I reported all this to Robert Kreba, but, because of prior commitments, he was unable to go with Nels.

On 22 May, I reached Paul James, Curator of Ornithology, SMNH, who was unaware of the Black Rail sightings, but was most interested and hoped he would be able to accompany Nels on a canoe trip. When I telephone Nels Arbinson on 28 May he told me he had gone back over the same route but, due to strong winds blowing the reeds, he did not see any birds. I learned then that he had made his first trip on 18 May during the forenoon, so he is actually the discoverer of the possible Black Rails.

I was back on the scene at Brown's Slough on 26 May, taking measurements with a pocket tape, and examining the locale. I found that the bank from the road edge slopes very steeply to the water's edge, the angle being $70^{\circ} \pm$, and the depth of the bank is $1.5 \mathrm{~m}$ (measured). The bank was thickly grassed so there was plenty of cover for such a tiny bird when it dropped down each time on my previous trip.

During the night of 17 May a southerly wind blew strongly which probably carried the Black Rail flight here. It is highly unlikely that the flight consisted of only six birds. Rather, I suspect that a colony lost its habitat and was forced to move, being caught up in the wind. Black Rails could have come down wherever they found likely habitat so there may be others scattered over much country. Since Black Rails are reported to come readily to taped calls, people interested in attracting these birds could explore likely places in this manner.

According to Godfrey, the Black Rail is on Canada's hypothetical list, there being two plausible sightings in Ontario and Quebec. ${ }^{2}$ Because of its secretive habits, its range is imperfectly known. Peterson indicates the closest breeding areas are in southeastern Minnesota, lowa and southeastern Nebraska.

My special thanks are due to Nels Arbinson, of 20 Birchwood Road, Regina, whose courteous cooperation helped me considerably.

1. BENT, A.C. 1927. Life histories of North American marsh birds. Dover, New York. 392 pp., plus 98 plates.

2. GODFREY, W. E. 1986. The birds of Canada. Nat. Mus. Canada, Ottawa. $595 \mathrm{pp}$.

3. PETERSON, R. T. 1980. A field guide to the birds of eastern and central North America. Houghton Mifflin, Boston. 384 pp. 